\title{
Application of Corporate Social Responsibility (CSR) in the Management of Housing Projects in Nigeria: Methodological Perspective
}

\author{
Achoru Afam Mike ${ }^{1 *}$, Achuenu Emmanuel², Daniel Maren Mallo ${ }^{3}$ \\ ${ }^{1,3}$ Dept. of Estate Management, Faculty of Environmental Sciences, University of Jos, Nigeria \\ ${ }^{2}$ Dept. of Building, Faculty of Environmental Sciences, University of Jos, Nigeria
}

*Corresponding Authors: Achoru Afam Mike, Dept. of Estate Management, Faculty of Environmental Sciences, University of Jos, Nigeria

\begin{abstract}
Mindful of the importance of a smooth housing project process especially towards economic sustainability, challenges have continued to undermine project performance. Housing project challenges which exist in each phase of a project life cycle border on the inability of project stakeholders to deliver the required and stipulated project expectations. Corporate social responsibility (CSR) which ensures that firms' act responsibly in service delivery has been applied in a multitude of ways by several researchers in the construction industry as well as housing projects, especially in developed nations. The need for the application of CSR in the management of housing projects by construction firms is vital as it presents potentials as a panacea to housing project challenges. However, CSR application in the management of housing projects as a panacea to housing project life cycle challenges remains unstudied which creates a gap that informed this study. Furthermore, relevant questions on its adoption and implementation in Nigerian housing projects can be best answered when an appropriate research methodology is used. The research methodology adopted for a doctoral research aimed at applying CSR in housing project management along project life cycle phases as a panacea to housing project challenges, is presented in this paper. This study adopted the research onion research design. This paper also outlines the research philosophy; approach; strategy; methods and choices. The reasons for the choices are justified as guided by the research onion. Also the research questions as well as relevant methodology literature were considered in the design. A major contribution of this paper is towards enumerating justifications for the adoption of research methods to address research questions.
\end{abstract}

Keywords: application, management, housing, project, methodology

\section{INTRODUCTION}

Nigeria's housing projects have continued to under-perform despite countless input on the path of both the public and private sectors which makes the housing situation a far cry from expectations. Leffat (2012) posited that under-performance in project activities exist within various phases of a housing project life cycle which make up the duration of a housing project. The life cycle phases of a housing project include: initiation, planning; design; execution and commissioning phase (Leffat, 2012). Ibem and Aduwo (2015); Joboye (2009) opined that challenges have continually marred the Nigeria housing project setting which has affected project delivery adversely to include the economy as a whole. Housing projects can deliver the expected levels of success if the challenges which abound in the different phases of a project life cycle are mitigated (Leffat, 2012). Ketut and Dwijendra (2013) noted that housing project challenges vary in nature which makes it quite daunting to address. The inability to promptly address challenges in a housing project can have a resulting and adverse effect on another aspect of the project hence the need to act early enough. The varying nature of African housing project challenges signifies the need for the best possible manpower, techniques and approaches to be used to guarantee project success (Muriithi \& Crawford, 2003). Project success in the opinion of Prabjheet (2011) entails that the responsibilities in every phase of a housing project life cycle is executed to ensure the satisfaction of clients and project stakeholders. This can only be achieved by ensuring that every existing challenge is addressed promptly and properly. 
Some of the challenges that have affected the success of housing projects include: inadequate amenities; poor attitude of project stakeholders; poor housing project sensitisation; inadequate project financiers; poor resource mobilisation; poor planning, poor scheduling to include poor organisational framework (Zami \& Lee, 2010). Abdellatif and Othman (2006) found the following challenges as being detrimental to the success and sustainability of housing projects: faulty project forecasting; poor project budgeting; lack of feasibility study; lack of viability study; failure to define a project early enough; poor resource distribution in a project setting; imminent diversion of project funds and inflation of contract quotes. Ibem and Aduwo (2015) noted some project challenges to border on: the poor attitude of project stakeholders; poor project fund allocation; poor project supervision and control; weak devolution of project activities; misuse of time and poor progress evaluation. Nwosu (2010) observed that Nigeria housing projects have suffered in the past due to: religious and tribal conflicts; constant site accidents; poor infrastructure and layout; weak project policies to include erratic housing project contract negotiations. Emerole (2002) posited that housing development in Nigeria has fallen short due to: unrealistic expectations from project partners; erratic contract negotiations; faulty project documentation; the death of a housing development financier; weak project initiatives; low government assistance in housing projects and the inability to pay contractors and employees.

In addition, Ugonabo and Emoh (2013) likened project challenges to factors such as poor project infrastructure and layout; poor project supervision and control; poor workmanship; inappropriate and faulty designs; the use of inferior building materials; poor devolution of responsibilities; delay in supplies; equipment breakdown during project execution; poor quality of materials to include the wastage of materials. Dweidri and Kablan (2006) advanced that projects usually suffer because project stakeholders fail to provide adequate amenities and infrastructure to see the project through. Jiboye (2009) noted that project developers often suffer due to the lateness in the delivery of project sites by clients. Afesis-corplan (2013) found that phases of a housing project life cycle are often prone to set-backs such as poor project communication; inconsistent project funding; failure to keep pace with project life cycle phases and a bad progress evaluation process which have all affected project performance in the life cycle phases.

Weary of the challenges faced during the course of housing projects over the years and their appalling effects, several attempts have been embarked upon as a panacea for these challenges. Jiboye (2009) noted that as a means to mitigate housing project challenges, proper layouts and improved infrastructure were often put in place prior to housing projects to ensure project success and in some cases, the projects still under-performed and even failed. Ibem and Aduwo (2015) advanced that housing projects employed strategies such as improved infrastructure; improved project site accessibility; project fund management plans; use of better professionals and technical abilities in housing projects; proper screening of building plans prior to housing projects and the supervision of material procurement and delivery which all contributed positively but still fell short of success in mitigating some challenges. The proper utilization and monitoring of equipment; improved screening of labour and materials; labour transportation to and from site and an enhanced materials management are some of the strategies employed towards solving housing project challenges to guarantee project success (Nwosu, 2010). Landon and Alken (2012); Aaltonen and Kujala (2010) noted that strategies such as regular stakeholder engagement and routine performance checks during the phases of projects have been used to limit housing project challenges which still persist. Kavishe (2018) found that inspection teams have often monitored PPP housing project sites and in some other cases, the use of direct/indirect labour has all been employed towards the mitigation of housing project challenges. These strategies employed gave different levels of success in mitigating some of housing project challenges but overall, challenges still persist which has continued to undermine the performance levels of housing projects. Considering the many challenges that have continuously been faced in the management of housing projects, it becomes necessary to re-strategise and as regards this study, investigate how the application of corporate social responsibility (CSR) can help to mitigate the challenges that undermine positive outcomes in the management of housing projects in Abuja, Nigeria considering that it is being employed on a large scale in developed nations and has recorded high success levels in various aspects of housing projects. 
CSR can best be understood by three words: 'Corporate', 'social' and 'responsibility' (Blowfield \& Frynas, 2005). 'Corporate', which means the services or practice which firms render in the environment. 'Social', being the ability of firms to engage the needs of stakeholders and society during the process of rendering services and 'responsibility' being the ability of firms to act responsibly in their endeavours (Blowfield \& Frynas, 2005). CSR is that which ensures that firms act responsibly and constructively as they go about their practice (Parkhe, 2014). CSR also relates to responsibilities which firms have towards society within which they are found and operate. Sung (2015) posited that through CSR, housing project firms can achieve: well designed houses; charitable activities; flexible working conditions for employees; mentoring and training programmes and much more into their housing project activities. These can go a long way in mitigating project challenges if adopted properly. Researchers such as Yam (2013); Yun and Lee (2011); Yam, Ismail and Tan (2011); Preston (2005) and Yin, Ismail and Hong (2004) all carried out studies in various developed countries and found with hard evidence the need to employ CSR in housing projects. It is in view of the challenges that have continuously been faced in the management of housing projects and the prospect of applying CSR that this study is set to propose the use of corporate social responsibility as a strategy to mitigate the challenges that undermine outcomes in the management of housing projects in Abuja, Nigeria.

\section{The Study}

The aim of this paper was to critically develop a methodology to effectively evaluate the application of CSR in the management of housing projects for the purpose of mitigating continuously occurring housing project challenges that has marred the housing projects over many years in Nigeria. To achieve this aim, a proper research design and methodology needed to be adopted. The choices for design and methodology are clearly outlined indicating reasons for the choices.

\section{RESEARCH DeSign AND METHOdOLOGY- LITERATURE REVIEW}

\subsection{Research Design}

Research is defined as a systematic investigation into the study of materials and sources in order to establish facts and reach new conclusions (Saunders, Lewis \& Thornhill, 2009). Mukul and Deepa (2011) posited that design is a work process which has a user perspective and drives development based on specific needs. Malhotra (2009) posited that the design of a study defines the study type (descriptive, co-relational, semi-experimental, experimental, review, meta-analytic) and sub-type (descriptive-longitudinal case study); research question; hypotheses; independent and dependent variables; experimental design; data collection methods and a statistical analysis. This then means that a design process can be said to vary between different projects and fields. A Research design can also then be considered as the structure of a research and the glue that bonds all of the elements in a research project together which equally makes research design a plan and strategy for a proposed research work. Research design is discussed by different social scientists in different ways.

Mukul and Deepa (2011) posited that research design exists in five categories namely: descriptive research design which is a theory-based research design and is created by gathering, analyzing and presenting collected data; Experimental research design which is used to establish a relationship between the cause and effect of a situation; co relational research design which is a non-experimental research design technique which helps researchers to establish a relationship between two closely connected variables; diagnostic research design in which a researcher is inclined towards evaluating the root cause of a specific topic and exploratory research design the researcher's ideas and thoughts are key as it is primarily dependent on their personal inclination about a particular topic. Research design in the opinion of Blaikie (2010) can be divided into two groups namely exploratory and conclusive. Exploratory aims at exploring specific aspects of a research without the intent of providing final and conclusive answers to research questions.

A research design should be made once the topic and problem of research has been selected and formulated, objectives have been properly outlined, concepts have been properly defined and the hypothesis have been properly framed (Kothari, 2010). This trend was adopted for the purpose of this research which was inclined towards the 'research onion' research design. Research onion' research design developed by Saunders, Lewis and Thornhill (2007), gives an overview of the stages to be 
engaged in during the course of developing a research study. The onion layers give a more detailed description of stages of a research process, where a researcher goes from the outer layer to the inner layer (Saunders, Lewis \& Thornhill, 2007). The research onion is such that the layers much be unwrapped within the onions from the outer layer to the center (see fig 1).For the inner layer to be seen, the outer layer ought to be removed first (Saunders, Lewis \& Thornhill, 2007). This study which centres on the application of CSR in housing projects which is a strategic and important practice will require prompt, precise and informed choices to be made along the onions in order to guide choices to achieve the best possible data collection and findings.

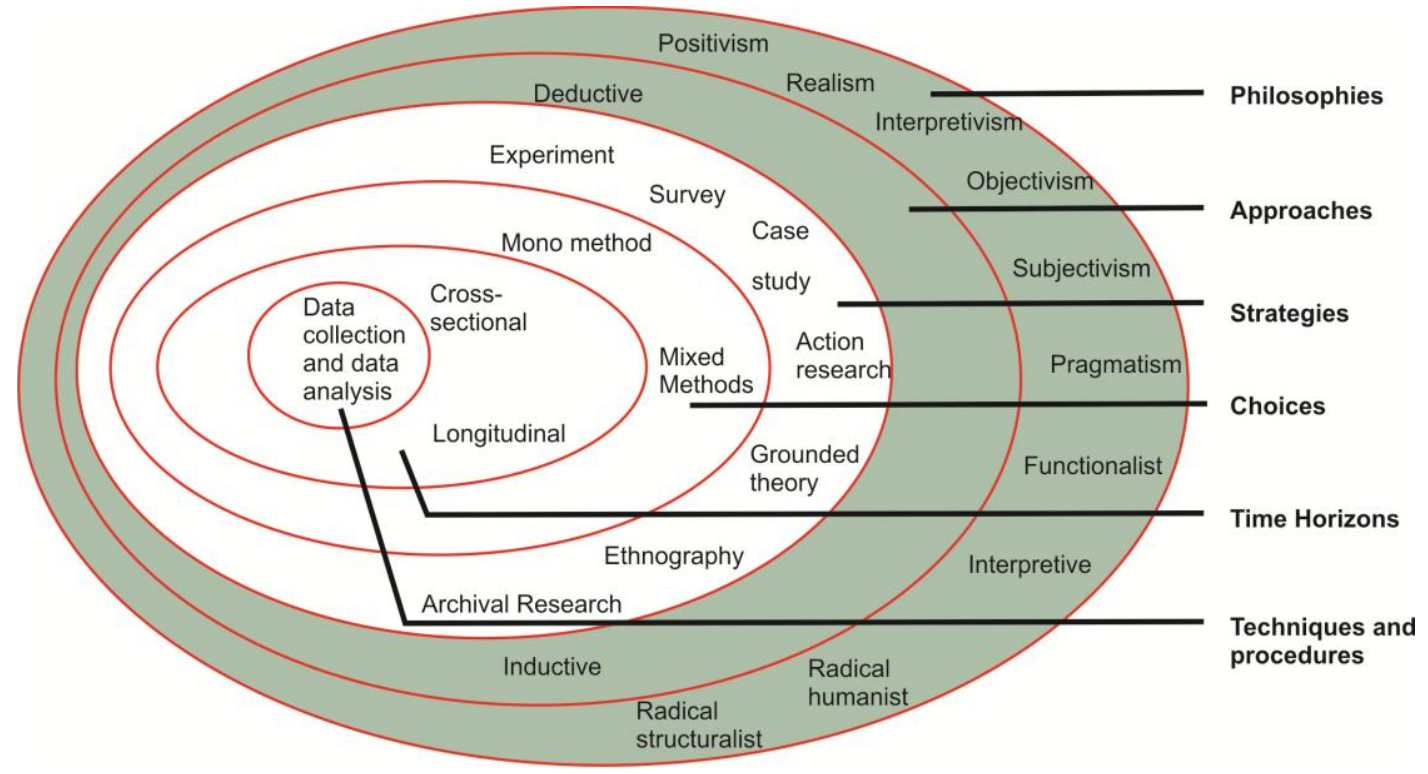

Figure1. The Research 'Onion' Research Design

Source: Saunders, Lewis and Thornhill, 2007.

\section{The Research Questions}

The research questions for this study were:

1. What are the challenges associated with the management of housing project life cycle phases in Abuja?

2. What is the level of adoption and implementation of CSR in the management of housing projects in Abuja?

3. How can CSR strategies be used in mitigating the challenges in the management of housing projects in Abuja?

4. What are the drivers and barriers in the adoption CSR in housing project management?

5. How can CSR be effectively applied in managing the phases of a housing project life cycle in Abuja, Nigeria?

\subsection{Research Philosophy}

Research philosophy refers to the development of knowledge adopted by researchers during the course of their research (Tufail, 2012). In other words, it is a theory that can be used to direct the researcher towards conducting the procedure of research design, research strategy, questionnaire design and sampling. Malhotra (2009) posited that philosophy is the study of the fundamental nature of knowledge, reality and existence especially when considered as an academic discipline and its methods include questioning; critical discussion; rational argument and systematic presentation. According to Mukul and Deeper (2013), three major ways of thinking about research philosophy is guided along the paths of: ontology, epistemology and axiology. Ontology is concerned with nature of reality, epistemology concerns what constitutes acceptable knowledge in a field of study and axiology studies judgements about value (Saunders, Lewis \& Thornhill, 2009). All three were employed for researcher and respondents interactions in this study. 
Ontology is the study of 'being' and is concerned with 'what is', in other words the nature of existence and structure of reality as such (Saunders, Lewis \& Thornhill, 2009) or what it is possible to know about the world (Snape \& Spencer, 2003). As regards this research, ontology aided in guiding the following questions: Does CSR exist in reality or is it a socially constructed phenomenon? Does CSR mean the same in the minds of researchers or does it have different meanings? Is the concept of CSR meaningful outside the mind? Is the concept of CSR applicable in managing housing projects, outside the mind? CSR guides service delivery by ensuring that housing project firms act legally, ethically, economically and philanthropically in their management functions in each phase of a housing project life cycle. Measures adopted in applying CSR in the management of housing project life cycle phases is of human perception and choice therefore the ontological claim for this research is inclined towards subjectivism.

Epistemology in general is an assumption usually made about the kind or the nature of knowledge (Tufail, 2012) or how it is possible to find out about the world (Snape \& Spencer, 2003). The choice of the epistemological stand for this study was clearly dependent on the nature of the research questions, which considered: CSR as being a social phenomenon with subjective meaning in line with inteprevist epistemology. The research questions being both descriptive (what) and explanatory (how) in nature suggested the application of both subjective and objective data, and quantitative and qualitative approaches (mixed design) for the purpose of achieving the research objectives. In light of this, a pragmatic philosophical approach will be adopted. Pragmatism is based on actions, situations and consequences which allow the use of quantitative and qualitative as well as combining approaches.

Axiology is the branch of philosophy that studies judgments about values including both of ethics and aesthetics (Silverman, 2001). Axiology can be value free of value laden depending on the relationship and element of control between the researcher and the researched. As regards this research, the researcher had authority over the methods and process of data collection because no external reality existed. Data on the effective management of housing projects through the application of CSR in each phase of a housing project life cycle was obtained and analysed with the use of different methods and techniques. Also, subjective meanings were attached and analysed by the researcher. The researcher was not completely independent because of interactions between the researcher and the researched which influenced the study value. Applying CSR in the management of housing projects was therefore positioned towards the value laden axiology.

\subsection{Research Approach}

Research approach is a plan and procedure that consists of the steps of broad assumptions to detailed method of data collection, analysis and interpretation (Lodico, Spaulding \&Voegtle, 2010). There are two approaches informing knowledge which are the inductive and deductive approaches. Inductive approach, also known in inductive reasoning starts with the observations and theories proposed towards the end of a research process as a result of observations (Mukul \& Deeper, 2013). A deductive approach is concerned with developing a hypothesis based on an existing theory and then designing a research strategy to test the hypothesis (Wilson, 2010).

This study aimed at tackling existing challenges in housing projects with a view to enhance the management of housing projects and this entailed a framework for effective management of housing projects through CSR application. This had to do with a combination of both design and explanatory sciences. The explanatory science (quantitative in nature) led to understanding the nature and causes of the research problem and was helpful in the design of solutions. Also, the design research (qualitative in nature) helped in the design of the solution itself. Mukul and Deeper (2013) posited that "what" and "how" line of research questioning ensures that providing answers would require a mix of qualitative and quantitative data. This study therefore adopted a mixed design method otherwise known as abductive approach. Mixed design researches make use of a pragmatic method (Snijar \& Lemau, 2007), as was the case with this study. The logic of enquiry included the use of induction (qualitative), deduction (quantitative) and abduction (best explanations for result understanding). Instruments of data collection and analysis concerning quantitative and qualitative methods were used concurrently to ensure that research questions were adequately answered. Pelenar (2008) noted that the use of both qualitative and quantitative approaches in a research enhances the quality of findings by using each of the methods to answer different research questions. 


\subsection{Research Strategy}

A research strategy is a step-by-step plan of action that gives direction to a researcher's thoughts and efforts, enabling the research to be conducted systematically and on schedule to produce quality results and detailed reporting (Babbie, 2010). Babbie (2010) identified different types of research strategy to be: experiment; survey; archival analysis; ethnography; grounded theory; history; case study; judgmental tasks; computer simulation; experimental simulations; field studies; field experiments; formal theories; sampling and surveys to include laboratory experiments. Open Learn University (2018) listed four main types of research strategies which others are hinged upon, to be: case study; qualitative interviews; quantitative survey and action-oriented research as presented in figure 2 .

This study determined measures that would enhance the practice of housing project management through CSR application to effectively tackle project challenges. Having listed and some of the research strategies, it was essential to key them in line with the nature of the research questions which were of the 'how' and 'what' types. 'How' and 'what' research questions signify descriptive and explanatory studies which made survey strategy unfit for this research as survey strategy deals with 'who', 'why', 'how many' and 'how much' questions. Considering that this research did not also aim at developing a new theory which grounded theory entails, the grounded theory was also inadequate for this research. The researcher also was not of a historical bearing as regards the research which is the crux of the historical survey, which made the historical survey a null and void for this research. The study also did not involve variables manipulation considering the "how" and "why" type which is the crux of experimental strategy, therefore this research also nullifies the use of experimental strategy. Also, the researcher was not part of the researched which is primary for the action oriented research which made the action research unfit. Lastly the study was considered within a stipulated time frame unlike a prolonged type of research which ethnography entails; therefore ethnography becomes an unsuitable strategy to advance this research.

The most appropriate strategy for advancing this research on the potentials of CSR application in the effective management of housing projects was the case study. Case study is applicable in a quantitative, qualitative as well as mixed design which makes it appropriate for use in studies that deal with pragmatic epistemological stance to include an abductive approach as were all the case in this research.

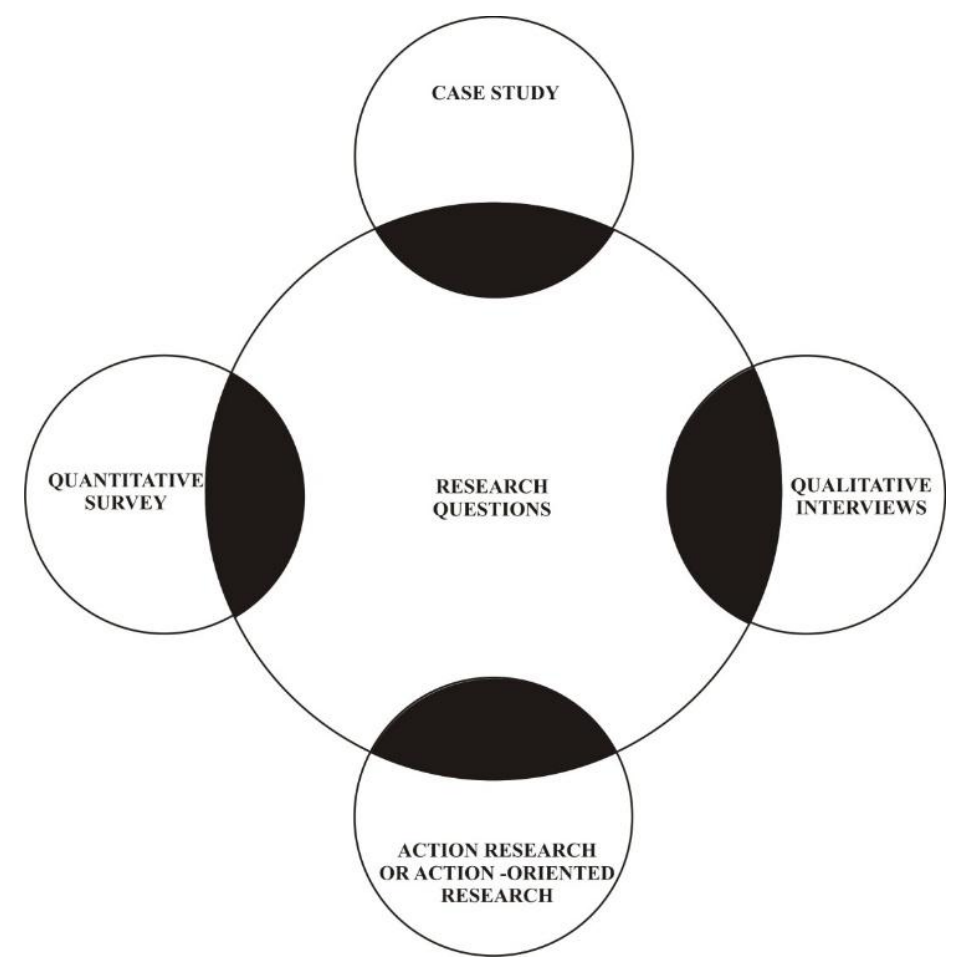

Figure2. Main Research Strategies

Source: Adopted from Open Learn University, 2018. 
Application of Corporate Social Responsibility (CSR) in the Management of Housing Projects in Nigeria: Methodological Perspective

Case Study Research Strategy: The case study was the most flexible of all research designs because it allows researchers to retain the holistic characteristics of real-life events while investigating empirical events (Pelenar, 2008). Case studies are only one of many ways of doing social science research with experimentation, observation, surveys and archival information each suited to a certain type of research problem, degree of experimenter control over events and historical/contemporary perspective and focus.

The crux of this study which centred on the application of CSR in the management of housing projects as a panacea to housing project challenges towards the improvement in quality and standards and success levels of project activities in housing projects, suggested the case study based on the quality of its components as aforementioned, as a form of research strategy. Also, its suitability lay in the fact that it was appropriate for investigation of contextually rich events or phenomena. It was also suitable because it most especially bothered on investigations which may be queried using the 'how' or 'why' line of questioning and where a researcher can exercise little control and which focuses on contemporary rather than historic information. A philosophical justification of the case study research strategy underpins the argument about the methodological merits of social science research strategy to include any other type of qualitative research strategy (Rose, Spinks \& Canhoto, 2015).

Validity and Reliability Tests in Case Study Research: Criteria for developing and evaluating case study methodology require logical tests of the validity and reliability of research tactics that have been used or planned (Abowitz \& Toole, 2010). Validity and reliability tests ensured that quality tactic was employed in the process of obtaining data on CSR and housing project challenges during the course of this study. Abowitz and Toole (2010) posited that researchers need to be familiar with validity and reliability tests, which have been expanded to include different tests of validity namely construct validity; internal validity and external validity, as well as a reliability test. Table 1 shows case study tactics for a four design test.

Table2. Case Study Tactics for a Four Design Test

\begin{tabular}{|c|c|c|}
\hline Tests & Case study & $\begin{array}{l}\text { Phase of research in which } \\
\text { tactics occurs }\end{array}$ \\
\hline \multirow[t]{3}{*}{ Construct validity } & Use multiple sources of evidence & - $\quad$ Data collection \\
\hline & - $\quad$ Establish chain of evidence & Data collection \\
\hline & $\begin{array}{l}\text { Have key informants review draft case } \\
\text { study report. }\end{array}$ & Composition \\
\hline \multirow[t]{4}{*}{ Internal validity } & Do pattern matching & Data analysis \\
\hline & Do explanation building & Data analysis \\
\hline & Address rival explanations & Data analysis \\
\hline & Use logic models & Data analysis \\
\hline \multirow[t]{2}{*}{ External validity } & Use theory in single-case studies & Research design \\
\hline & $\begin{array}{l}\text { - Use replication logic in multiple-case } \\
\text { studies }\end{array}$ & Research design \\
\hline \multirow[t]{2}{*}{ Reliability } & Use case study protocol & Data collection \\
\hline & Develop case study data base & Data collection \\
\hline
\end{tabular}

For this study which involved the application of CSR in the management of housing projects as a panacea to housing project challenges, construct validity was addressed by collecting data from professionals in construction firms actively engaged in housing projects otherwise known as housing project management firms to include professionals from Federal Capital Development Authority (FCDA) and the preliminary case study report was validated by housing project stakeholders and occupiers in the built environment. The results obtained from the interviews were also analysed during which emerging themes were cross matched and explanations provided for divergent responses which ensured that internal validity was achieved. For external validity to also be achieved, credible methodologies used to address similar research problems in the construction industry were adopted 
while reliability was achieved through the use of quality questionnaires and case study protocol which helped as a guide in obtaining quality CSR information from the selected housing project management firms', FCDA and housing end users.

\section{Research Methods and Choices}

A research method is a systematic plan for conducting a research. Researchers draw on a variety of both qualitative and quantitative research methods, including experiments, survey research, participant observation and secondary data (Jess, 2013). Quantitative methods aim to classify features, count them and create statistical models to test hypotheses and explain observations while qualitative methods aim for a complete detailed description of observations, including the context of events and circumstances. A study population means the aggregate of all elements under study having one or more common characteristic (Jess, 2013). The population of this study was unknown in nature as it dealt with the total number of professionals (registered and unregistered) in the construction industry in Abuja which could not be determined. Sample means choosing a part of a population at random for participation in a research (Babbie, 2010). A selected sample should be such that it represents the population in all its characteristics and it should be free from bias so as to produce miniature crosssection, as the sample observations are used to make generalizations about the population (Jess, 2013). The sample size consisted of professionals in the construction industry involved in the housing project delivery through CSR application strategies. Taylor (2012) suggested that a sample of 300-500 may be adequate for an unknown population in a representative survey. Isreal (2009) posited that sample sizes of similar studies can also be adopted to advance a research. Similar research studies of Preston (2005) and Yun and Lee (2011) adopted sample sizes of 350 and 400 respectively. Sequel to the opinions of Taylor (2012) and Israel (2009), a sample size of 300 was adopted for this study.

The method of collecting research data is synonymous with research strategy. This study which centred on the application of CSR in housing projects adopted a case study strategy with research questions. The various techniques for collecting data in case study research include interviews; questionnaire survey; documentation; archival records; direct observations; physical artefacts and participant observation (Yin, 2003).This study adopted interviews, questionnaires and survey of documents as the instruments of data collection. The adoption was based on the nature of the research questions to include the research purpose. Furthermore, questionnaire and interview guided the primary data while survey of project and CSR documents guided the secondary data. The targeted respondents were grouped into: clients, employees, consultants and contractors.

The selection of respondents for questionnaire and interview was done with an attempt to target quality respondents such that reliable data would be gathered and analysed. A pilot study was carried out to test the quality and appropriateness of the questions. Purposive sampling technique was used to select respondents for the administering of questionnaires. Purposive sampling technique is used when a researcher intends to select participants with experience in a key concept (Wilson, 2010). Lodico, Spaulding and Voegtle (2010) advanced that purposive sampling technique can also be used when the sample is small and the sampling error is likely to be so large that biases are inevitable to include, when the characteristics of the whole population is not known. Judgemental sampling technique was used to select respondents for the interviews. Judgemental sampling method was used because it helps in the selection of respondents with experience in a particular subject of study. Snape and Spencer (2003) posited that judgmental sampling technique can serve for specific purposes such as in cases where researchers use their judgment to select a sample based on appropriate sample characteristics. For this study, judgement was based on respondent's roles and responsibilities as well as experiences in housing project challenges, the use of CSR in housing project management and satisfaction levels with housing project outcome. The professional respondents were grouped under professions of: architecture, building; quantity surveying and engineering.

Choosing a case study is much easier if a researcher has a strong foundation of what the research topic is all about (McNamara 2010). There were various housing projects in progress being managed through CSR strategy during the scouting process for appropriate case study selection for this research. To achieve an exhaustive survey and data gathering, four case studies were selected for this study. Among the selected cases, two were firms with completed mass housing projects while the other two were firms with uncompleted (ongoing) mass housing projects. The housing estates in all 
four cases all comprised of houses with various accommodation types, styles, sizes and prices. The geographical locations of the cases were also considered to ensure a good geographical spread and coverage within Abuja metropolis. The four case studies proved to be adequately grounded as regards various kinds of housing project challenges faced; CSR implementation and strategies; stakeholder engagement at all project levels; the ability to integrate CSR values and vision; ability to set appropriate goals and targets to include CSR monitoring and feedback.

Methods of data analysis are also known as data analysis tools. Data analysis is a process of inspecting, cleansing, transforming and modelling data with the goal of discovering useful information, informing conclusions and supporting decision-making (Abowitz \& Toole, 2010). Parametric and non-parametric tests were adopted to achieve an exhaustive data analysis. The data analysis tools used for this study included: Content analysis; Mean rating and Analysis of Variance (ANOVA) for parametric testing and Kruskal-Wallis test ( $\mathrm{H}$ test) for non-parametric testing. Content analysis was helpful because this study dealt with corporate social information from respondents directly or indirectly involved in managing housing projects. Mean rating was vital for this research not only for its usefulness and importance for data analysis in all aspects of research but because this study will entail CSR scores which will be collated from housing project respondents. ANOVA was employed to test the relationship between the above groups. ANOVA was also relevant for research because it can be employed along with mean rating in data analysis. This study dealt with questionnaires on CSR and housing projects which required ranking hence the adoption of the $\mathrm{H}$ test for analysis. Kruskal Wallis tests also complement mean rating and ANOVA in data analysis as it can be used as back-up when assumptions are not met.

\section{Survey of CSR and Housing Project Documents}

Document analysis is a form of qualitative research in which documents are sighted and interpreted by a researcher to give voice and meaning around an assessment topic (Bowen, 2009). Documents relating to housing projects and CSR application were also be sighted and examined in addition to the questionnaires and interviews. Some of the surveyed documents include: cumulated documents on the trend of housing project challenges experienced in past and ongoing projects; firms' policy documents on housing project structure; policy documents as regards the application of CSR; management reports on housing project challenges and CSR. These documents were examined to determine the adequacy or inadequacy of available regulatory frameworks for the application of CSR concept in determining efficiency in housing production through a streamlined housing project management, an enhanced project delivery, possibility of shareholder satisfaction, improvement of firms' reputation and standing, firms' profitability to include an improved shareholder and stakeholder satisfaction.

\section{Development and Validation of Framework}

A framework is a basic conceptual structure used to solve or address complex issues, usually a set of tools, materials or components (Montenegro \& Fontoura, 1999). A framework presents an overview of challenges and a suitable pathway towards solving the challenges while the validation ensures the credibility of its use. A major importance of developing and validating a framework is that it serves as a means for prescribing or evaluating solutions to research problems. Framework development and validation on application of CSR in the management of housing projects will be enhanced because the framework will help to identify important new issues and prescribe the most critical research questions that need to be answered to maximize understanding of the issue. Also, the framework will serve as a means to guide and inform this research (which is still ongoing) so that it could equally guide other research efforts and improve professional practice in the management of future housing projects. The framework to be developed and proposed in this study will give a clearer picture of the adoption and implementation of CSR in the management of housing projects as a panacea to the continuously existing housing project challenges.

\section{The Study Area}

Abuja is the capital city of Nigeria. It is located around the centre of Nigeria, within the Federal Capital Territory (FCT). Abuja like many other cities is a planned and was built mainly in the 1980s. It became Nigeria's capital city the on $12^{\text {th }}$ day of December 1991, replacing Lagos (the country's most populous city). The inhabitant tribes of Abuja are the Gbagyi (Gwari) which is the major language, Mada, Ganagana, Koro and Mada. Abuja's geography is defined by Aso Rock, a 400-metre 
monolith left by water erosion. The Presidential Complex, National Assembly, Supreme Court and much of the city extend to the south of the rock. Zuma Rock, a 792-metre monolith, lies just north of the city on the road to Kaduna State.

At the 2006 census, the city of Abuja had a population of 776,298 making it one of the ten most populous cities in Nigeria (Population Council, 2007). The United Nations highlighted that Abuja rapidly grew at an annual rate of $139.7 \%$, between the years 2000 to 2010 which makes it the fastest growing city in the world. As at 2015, the city was still experiencing an annual growth of at least $35 \%$, still retaining its position as the fastest growing city on the African continent and one of the fastest in the world (Abuja Facts, 2015). Abuja has and still witnesses a huge influx of people into the city. The growth has enabled the emergence of many satellite towns. Abuja is also rapidly grown into neighbouring Nasarawa and Niger states.

With a vast number of construction companies with various experienced professionals in practice, located within various geographical locations in Abuja, the city represented an appropriate setting as study area for this research. Many housing projects have been and are still being embarked on in Abuja. Preliminary investigations equally indicated the application of CSR in housing project practices by a number of firms' in the study area, which made it adequate to have advanced this study. Furthermore, a good road network within Abuja always made accessibility much easier for data collection. Several modes of transportation existent in Abuja also ensured comfort and convenience while accessing case studies, FCDA and housing end users.

\section{Conclusion}

This paper presents the research methodology of an almost completed doctoral research aimed at managing housing projects with the application of corporate social responsibility as a panacea to the ever-existing housing project challenges. A step by step process of selecting research methods towards addressing the research questions of this study has been looked at. Effort has been made to discuss the existing literature that can guide the path of research design and strategise selection towards advancing a research. This study adopted the research onion research design as already established. This study also established the need for the adoption of ontology, epistemology and axiology for philosophical purpose as their adoption enhances better research quality. The study also adopted a mixed design otherwise known as abductive approach as strategy. The study adopted a case study research strategy guided by validity and reliability tests to ensure quality of data and analysis. Quality questionnaires and case study protocols were designed to guide the research which was further subjected to a pilot study. Purposive and judgemental sampling techniques were used to select respondents for questionnaire and interview protocols respectively. CSR and housing project documents were also surveyed to enable quality of data and analysis. The measures taken to ensure acceptability of the findings are also discussed in this paper. Early findings indicated positive inclination towards CSR application as a valid strategy to address housing project challenges in Abuja. Recommendations will be geared towards ensuring efficiency, quality, adequacy and satisfaction in the management of Nigerian housing projects by suggesting ways towards mitigating housing project challenges in the phases of a housing project life cycle, which can be achieved through effective corporate social responsibility application.

\section{REFERENCES}

[1] Aaltonen, K., \& Kujala, J. (2010). A Project Lifecycle Perspective on Stakeholder Influence Strategies in Global Projects. Scandinavian Journal of Management, Elsevier, 26:381-397.

[2] Abdellatif, M.A., \& Othman, A.A.E. (2006). Improving the Sustainability of Low Income Housing Projects: The case of Residential Buildings in Musaffah Commercial City, Abu Dhabi. Emirates Journal for Engineering Research, 11(2), 47-58.

[3] Abowitz, D., \& Toole, T. (2010). Mixed Method Research: Fundamental Issues of Design, Validity, and Reliability in Construction Research, Journal of Construction Engineering and Management, 136, 108116.

[4] Abuja Facts (2015). Top 5 Cities To Do Business In Nigeria. Abuja is $2^{\text {nd }}$. Retrieved July 14. 2018, from https://web.archive.org/web/20160204113031/http://www.abujafacts.ng/top-5-cities-to-do-business-innigeria-abuja-is-2nd/.

[5] Adenuga, O. A. (2013). Factors Affecting Quality in the Delivery of Public Housing Projects in Lagos State, Nigeria. International Journal of Engineering and Technology, 3 (3), 332-344. 
[6] Aduwo, E.B. (2011). Housing Transformation and its Impact on Neighbourhoods in Selected Low-Income Public Housing Estates in Lagos, Nigeria. Ph.D. thesis submitted to Covenant University Nigeria.

[7] Afesis-Corplan, (2013). Housing Project Life Cycle. Retrieved November 27. 2018 from http://afesis.org.za/wp content/uploads/2017/05/Housing_delivery_process_final.pdf.

[8] Akinola, W. (2017). How Nigeria Can Tackle Housing Deficit In 2017. Retrieved April 18. 2018, from https://www.naij.com/1084149-how-nigeria-tackle-housing-deficit-2017.html.

[9] Amaeshi, K. M., Adi, B. C., Ogbechie, C., \& Olufemi, O. A. (2006). Corporate Social Responsibility in Nigeria: Western Mimicry or Indigenous Influences?' Journal of Corporate Citizenship, 24, 83-99.

[10] Babbie, E. R. (2010). The Practice of Social Research. Cengage Learning.

[11] Barone, M.J., Miyazaki, A.D., \& Taylor, K.A. (2000). The Influence Of Cause-Related Marketing on Consumer Choice: Does One Good Turn Deserve Another? Journal of the Academy of Marketing Science, 28 (1), 248-262.

[12] Blaikie, N. (2010). Designing Social Research. 2nd Edition, Polity.

[13] Blowfield, M., \& Frynas, J.G. (2005). Setting New Agendas: Critical Perspectives on Corporate Social Responsibility in The Developing World. International Affairs. 81 (3), 499-513.

[14] Bowen, G. A. (2009). Document Analysis as a Qualitative Research Method. Qualitative Research Journal, 9 (2), 27-40.

[15] Dweiri, F. T., \& Kablan, M. M. (2006).Using Fuzzy Decision Making for the Evaluation of Project Management Internal Efficiency. Decision Support Systems, 42, 712-726.

[16] Ekong, S., Ujene, A., \& Ubong, U., (2014). Drivers of Corporate Social Responsibility within Construction Organizations in Nigeria. International Letters of Social and Humanistic Sciences, 32, 14-25.

[17] Emerole, C.G. (2002). Restructuring Housing Development and Financing in Nigeria: The Role of Partnership and Collaboration Strategies Housing Today. The Journal of the Association of Housing Corporations of Nigeria (AHCN), 1(5): 26-29.

[18] Ibem, E.O., \& Aduwo, E.B. (2015). Assessment of the Sustainability of Public Housing Projects in Ogun State, Nigeria: A Post Occupancy Evaluation Approach. Mediterranean Journal of Social Sciences, 6(4), 523-535.

[19] Igwe, P.U., Okeke, C.A., Onwurah, K.O., Nwafor, D.C. and Umeh, C.N. (2017). A Review of Housing Problems. International Journal of Environment, Agriculture and Biotechnology, 2(6), 3092 - 3099.

[20] Jess, G.V. (2013). Research Strategy in the Modern Era Practice. MA. Blackwell Publishers.

[21] Jiboye, A.D. (2009). The Challenges of Sustainable Housing and Urban Development in Nigeria. Journal of Environmental Research and Policies. 4 (3), 23-27.

[22] Kavishe, N. (2018). Risks Associated with Public Private Partnership (PPP) Housing Projects Delivery in Tanzania, International Journal of Construction Engineering and Management, 7 (2), 81-87.

[23] Ketut, N. \& Dwijendra, A. (2013). Quality of Affordable Housing Projects by Public and Private Developers in Indonesia: The Case of Sarbagita Metropolitan Bali. Journal of Geography and Regional Planning, 6 (3), 69-81.

[24] Kolk, A., \& Pinkse, J. (2006) Stakeholder Mismanagement and Corporate Social Responsibility Crises. European Management Journal, 24, 59-72.

[25] Kotler, P. \& Lee, N. (2005). Corporate Social Responsibility: Doing the Most Good for Your Company and Your Cause. Wiley, Hoboken, NJ.

[26] Kothari, C.R., (2010). Research Methodology: Methods and Technique. New Delhi: New Age International Publishers.

[27] Landon, D.A. \& Alken S.D, (2012). The Life Cycle Phases of Construction Projects: Key Issues and Solution. Van Nostrand Reinhold, New York.

[28] Lefat, B.F. (2012). Challenges Associated with the Sustainable Management of a Housing Project Life Cycle: A study of Myanmar Rural, Asian Journal of Civil Works, 11(2), 12-23.

[29] Lodico, M.G., Spaulding, D.T \&Voegtle, K.H. (2010). Methods in Educational Research: From Theory to Practice. John Wiley \& Sons.

[30] Logan, D., Delwin, R., \& Regelbrugge, L. (1997). Global Corporate Citizenship: Rationale and Strategies. The Hitachi Foundation, Washington, DC.

[31] Malhotra, N. (2009). Marketing Research: An Applied Orientation takes a unique applied and managerial orientation that illustrates the interaction between marketing research decisions and marketing management decisions. Prentice Hall 2009. 
Application of Corporate Social Responsibility (CSR) in the Management of Housing Projects in Nigeria: Methodological Perspective

[32] Montenegro, M.F., \& Fontoura, C.D. (1999). A Systematic Approach to Framework Development. A PhD Dissertation presented to the Computer Science Department of the Pontifical Catholic University of Rio de Janeiro, July, $5^{\text {th }} 1999$.

[33] McNamara, S. A. (2010). Research Design in Management Sciences. New York: Routledge Publication, USA.

[34] Mukul, G., \& Deepa, G. (2013). Research Methodology. PHI Learning Pvt. Ltd.

[35] Mukul, G., \& Deepa, G. (2011). Research Methodology, New Delhi: PHI Learning Private Limited.

[36] Muriithi, N., \& Crawford, L. (2003). Approaches to project management in Africa: implications for international development projects. International Journal of Project Management, 21 (5), 309-319.

[37] Nwosu, C.A. (2010). The Undermining factors of Nigeria Housing Project failures. ABEL Printers, Aba.

[38] Ofori, D.F. \& Hinson, R.E. (2007). Corporate Social Responsibility (CSR) Perspectives Of Leading Firms in Ghana, Journal of Corporate Governance, 7 (2), 178-193.

[39] Parkhe, D. (2014). How will India's new CSR Law Influence and Impact the C suite.

[40] Pelenar, D. (2008). Social Science Research Made Easy. Hernaio \& Co. Publishing.

[41] Prabjheet, D. (2011). Housing Project Life Cycle Phases: Challenges and Solution. IJMBL, 2 (4), 12-21.

[42] Preston, L.H.N. (2005). Adopting Corporate Social Responsibility in Housing Project Delivery: A case of selected projects in Ballarat, Australia. Australian Journal of quality and reliability management, 11(4), 56-67.

[43] Rose, S., Spinks., N., \& Canhoto, A.I. (2015). Management Research: Case Study Research Design Principles. Applying the Principles.

[44] Saunders, M., Lewis, P., \& Thornhill, A. (2009). Research Methods for Business Students. Prentice Hall, Pearson, New York.

[45] Silverman, D. (2001). Interpreting Qualitative Data: Methods for Analysing Talk, Text and Interaction (2nd ed.). London: Sage.

[46] Snape, D., \& Spencer, L. (2003). The foundations of qualitative research. In J. Richie \& J. Lewis (Eds.), Qualitative Research Practice. Los Angeles: Sage.

[47] Snijar, R. \& Lemau, K. (2007). The Art of Research Methodology: An Academic Guide for Students and their Mentors, Aujibar Kailias Press.

[48] Sung, D.S. (2015). Partnership as a Corporate Social Responsibility Tool for Housing Project Stakeholders. Yiang-Zi Publishing Company, Tai Po Hong Kong.

[49] Tufail, M. (2012). Branches of Philosophy: Axiology. Presentation (PDF) on October 2012. Retrieved March 18. 2018, from https://www.researchgate.net/publication/288493407_Axiology.

[50] Ugonabo C.U., \& Emoh, F.I. (2013). The Major Challenges to Housing Development and Delivery in Anambra State of Nigeria. Civil and Environmental Research, 3(4), 1-19.

[51] Waddock, S. (2004). Parallel Universes: Companies, Academics, and the Progress of Corporate Citizenship, Business and Society Review, 109, 5-42.

[52] Walker, D.H.T., Segon, M. \& Rowlinson, S. (2008). Business Ethics and Corporate Citizenship, In Walker, D.H.T. And Rowlinson, S. (Eds), Procurement Systems: A Cross Industry Project Management Perspective, Taylor \& Francis, 101-139.

[53] Wilson, J. (2010). Essentials of Business Research: A Guide to Doing Your Research Project. SAGE Publications.

[54] Yam, L.H.S., Ismail, M., \& Tan, S.Y. (2008). Corporate Social Responsibility in Malaysia Housing Development: The Developer's Perspective, Pacific Rim Property Research Journal, 14, (2), 177-198.

[55] Yin, P.K. (2003). Case Study Research: Design and methods. $4^{\text {th }}$ ed. Thousand Oaks, CA: SAGE.

[56] Yun, L.D., \& Lee, K. (2011). New Strategies for Firms - The Implementation of CSR in Housing Projects in Yishun City, Singapore. Asian Journal of Technology and Management in Construction, 3 (1), 113-124.

[57] Zami, M.S., \& Lee, A. (2010). Misunderstanding of Housing and its Influence on the Success of Low Cost Housing Projects: State of the Art Review. The Built \& Human Environment Review, 3(1-11).

Citation: Achoru Afam Mike,et.al., "Application of Corporate Social Responsibility (CSR) in the Management of Housing Projects in Nigeria: Methodological Perspective", International Journal of Research in Environmental Science (IJRES), vol. 6, no. 2, pp. 9-20, 2020. Available: DOI: http://dx.doi.org/10.20431 /2454-9444.0602002

Copyright: (C) 2020 Authors. This is an open-access article distributed under the terms of the Creative Commons Attribution License, which permits unrestricted use, distribution, and reproduction in any medium, provided the original author and source are credited. 